Article

\title{
Energy Saving Potentials of Phase Change Materials Applied to Lightweight Building Envelopes
}

\author{
Yoon-Bok Seong ${ }^{1}$ and Jae-Han Lim ${ }^{2, *}$ \\ 1 Integrated Research Institute of Construction and Environmental Engineering, College of Engineering, \\ Seoul National University, Seoul 151-744, Korea; E-Mail: nike21@snu.ac.kr \\ 2 Department of Architectural Engineering, Ewha Womans University, Seoul 120-750, Korea \\ * Author to whom correspondence should be addressed; E-Mail: limit0@ewha.ac.kr; \\ Tel.: +82-2-3277-6874; Fax: +82-2-3277-2437.
}

Received: 21 August 2013; in revised form: 20 September 2013 / Accepted: 23 September 2013 / Published: 14 October 2013

\begin{abstract}
Phase change materials (PCMs) have been considered as an innovative technology that can reduce the peak loads and heating, ventilating and air conditioning (HVAC) energy consumption in buildings. Basically they are substances capable of storing or releasing thermal energy as latent heat. Because the amount of latent heat absorbed or released is much larger than the sensible heat, the application of PCMs in buildings has significant potential to reduce energy consumption. However, because each PCM has its own phase change temperature, which is the temperature at which latent heat is absorbed or released, it is important to use an appropriate PCM for the purpose of building envelope design. Therefore, this paper aims to investigate the energy saving potentials in buildings when various PCMs with different phase change temperatures are applied to a lightweight building envelope by analyzing the thermal load characteristics. As results, the annual heating load increased at every phase change temperature, but the peak heating load decreased by $3.19 \%$ with heptadecane (phase change temperature $21^{\circ} \mathrm{C}$ ), and the lowest indoor temperature increased by $0.86{ }^{\circ} \mathrm{C}$ with heptadecane (phase change temperature $21^{\circ} \mathrm{C}$ ). The annual cooling load decreased by $1.05 \%$ with dodecanol (phase change temperature $24{ }^{\circ} \mathrm{C}$ ), the peak cooling load decreased by $1.30 \%$ with octadecane (phase change temperature $29{ }^{\circ} \mathrm{C}$ ), and the highest indoor temperature dropped by $0.50{ }^{\circ} \mathrm{C}$ with octadecane (phase change temperature $29{ }^{\circ} \mathrm{C}$ ). When the night ventilation was applied to the building HVAC system for better passive cooling performance, the annual cooling load decreased by $9.28 \%$ with dodecanol (phase change temperature $24{ }^{\circ} \mathrm{C}$ ), the peak load
\end{abstract}


decreased by $11.33 \%$ with octadecane (phase change temperature $29{ }^{\circ} \mathrm{C}$ ), and the highest indoor temperature dropped by $0.85^{\circ} \mathrm{C}$ with octadecane (phase change temperature $29^{\circ} \mathrm{C}$ ).

Keywords: phase change materials (PCMs); lightweight building envelope; heating load; cooling load; phase change temperature

\section{Introduction}

Phase change materials (PCMs) have been considered as an innovative technology that can reduce the peak loads and heating, ventilating and air conditioning (HVAC) energy consumption in buildings. Basically they are substances capable of storing or releasing energy as latent heat. Because the amount of latent heat absorbed or released is much larger than the sensible heat, the application of PCMs in buildings has significant potential to reduce energy consumption [1]. However, because each PCM has its own phase change temperature, which is the temperature at which latent heat is absorbed or released, it is important to use an appropriate PCM for the purpose of building envelope design. PCMs can play an important role in reducing the heating and cooling load in buildings by utilizing their high storage density and latent heat capacity. In particular, the increased use of fully glazed facades in most modern office buildings results in an increase in the internal and external loads because such a lightweight building envelope lacks heat storage capabilities. Thus, the application of PCMs in such buildings, in which a large material mass is absent, can be an efficient way to decrease the heating and cooling loads because the PCM conserves thermal energy. A PCM changes its phase depending on the operating temperature and this phase change temperature varies according to the type of PCM. The phase change temperature is the most significant factor that affects the heating and cooling load because the energy is absorbed or released at the solid-liquid or liquid-solid transition temperature. Therefore, this paper aims to investigate the energy saving potentials in buildings when the various PCMs are applied to a lightweight building envelope by analyzing the thermal load characteristics according to the various phase change temperatures of PCMs.

\section{PCMs for Building Materials}

\subsection{Application of PCMs for Building Materials}

Building energy consumption accounts for a significant part of the energy use in the world. Therefore it is important to improve the energy efficiency of buildings. In energy efficient buildings such as passive houses, zero energy buildings, and zero emission buildings, high performance thermal insulation, building air-tightness and high performance ventilation systems are regarded as prerequisites [2]. Also the effective thermal energy storage and release can lead to the peak reduction of building heating and cooling loads. PCMs have been introduced as an innovative way to reduce the cooling and heating demand of buildings by using effective thermal energy storage. PCMs represent a technology that may reduce peak loads and HVAC energy consumption in buildings. They are used by melting with a latent heat of fusion in a unique temperature range. It is generally known that they can store five to fourteen times more heat per unit volume than sensible heat storage materials, such as 
water, masonry, or rock [3]. Basically the three different ways to use PCMs for heating and cooling of buildings are: (i) PCMs in building walls; (ii) PCMs in building components other than walls; and (iii) PCMs in heat and cold storage units [4]. For this purpose, a PCM can be incorporated either in gypsum or in concrete, but in almost all cases, PCMs have to be encapsulated for technical use, as otherwise the liquid phase would be able to flow away from the location where it is applied. There are two different methods for encapsulation of PCM. The first is micro-encapsulation, whereby small, spherical or rod-shaped particles are enclosed in a thin, high molecular weight polymeric film. The second is macro-encapsulation, which comprises the inclusion of PCM in some form of package such as tubes, pouches, spheres, panels or other receptacles. These containers can serve directly as heat exchangers or they can be incorporated in building products. Macro-encapsulation is the most common form of encapsulation. Micro-encapsulation is a recently developed new form of encapsulation for PCM. Several researchers have developed the encapsulation methods of the PCM $[3,5,6]$. The PCMs to be used in the thermal storage system should possess desirable thermo-physical, kinetic and chemical properties. Generally the PCMs are categorized as organic, inorganic and eutectic materials from the point of view of basic chemical composition, which have different melting temperature and latent heat of fusion. Among the investigated PCMs, paraffins have been widely used for latent heat storage in building applications because of their large latent heat and appropriate thermal characteristics, such as little or no super cooling, low vapor pressure, good thermal and chemical stability, and self-nucleating behavior. The paraffins are a mixture of pure alkanes which have quite a wide range of phase change temperatures, but these paraffins have low thermal conductivity compared to inorganic materials. Commercial paraffin waxes are cheap with moderate thermal storage densities and a wide range of melting temperatures.

\subsection{Physical Properties of the PCM}

Four types of paraffin-based material, hexadecane, heptadecane, dodecanol and octadecane, were selected to serve as the PCM that is contained in the supporting material. The melting temperature and the heat capacity of each PCM were measured by using a differential scanning calorimeter (DSC) instrument (DSC Q1000, TA Instrument, New Castle, DE, USA). DSC measurements were performed at a $5{ }^{\circ} \mathrm{C} / \mathrm{min}$ heating rate in the temperature range of $0-80{ }^{\circ} \mathrm{C}$. The melting temperature was measured by drawing a line at the point of maximum slope of the leading edge of the peak and extrapolating to the base line. The total latent heat of the PCMs was determined by numerical integration of the area under the peaks that represents the solid-solid and solid-liquid phase transition.

The thermal conductivity of PCMs was measured by using a TCi thermal conductivity analyzer. The TCi, developed by C-Therm Technologies Ltd. (Fredericton, NB, Canada), is a device for conveniently measuring the thermal conductivity of a small sample by using the Modified Transient Plane Source (MTPS) method. Contrary to other devices, TCi can measure the thermal conductivity of materials in solid, liquid, powder, and mixed states. The TCi consists of a sensor, a power control device, and computer software. A spiral-type heating source is located at the center of the sensor, and heat is generated at the center. The heat that has been generated enters the material through the sensor, at which point a voltage decrease occurs rapidly at the heating source, and the thermal conductivity is calculated 
through the voltage decrease data. Table 1 shows the overall properties of each PCM, which were measured as described above.

Table 1. Physical properties of phase change materials (PCMs).

\begin{tabular}{ccccc}
\hline Properties & Hexadecane & Heptadecane & Dodecanol & Octadecane \\
\hline Melting point $\left({ }^{\circ} \mathrm{C}\right)$ & 20 & 21 & 24 & 29 \\
Conductivity $(\mathrm{W} / \mathrm{m} \mathrm{K})$ & 0.39 & 0.33 & 0.28 & 0.26 \\
Density $\left(\mathrm{kg} / \mathrm{m}^{3}\right)$ & 777 & 773 & 853 & 777 \\
Specific heat $(\mathrm{J} / \mathrm{kg} \mathrm{K})$ & 1,390 & - & 1,550 & 1,200 \\
Latent heat $(\mathrm{J} / \mathrm{kg})$ & 281,000 & 230,000 & 235,000 & 267,000 \\
Thickness $(\mathrm{m})$ & 0.0064 & 0.0064 & 0.0064 & 0.0064 \\
\hline
\end{tabular}

\section{Simulation Methods}

\subsection{Mathematical Model}

The studied building is an eight-story research building located in Seoul. This building has a lightweight building envelope. The exterior wall of this building consists of galvanized steel sheet, air cavity, insulation and gypsum board from outside to inside. In addition, four PCMs with different phase change temperatures were evaluated by considering the heating and cooling set-point temperatures of $22^{\circ} \mathrm{C}$ and $26^{\circ} \mathrm{C}$, respectively: These were hexadecane $\left(20^{\circ} \mathrm{C}\right)$, heptadecane $\left(21^{\circ} \mathrm{C}\right)$, dodecanol $\left(24^{\circ} \mathrm{C}\right)$ and octadecane $\left(29^{\circ} \mathrm{C}\right)$. In this study, firstly the physical properties of each PCM were measured with laboratory tests. An energy simulation with EnergyPlus was performed assuming that PCM was applied between the insulation and the gypsum board of the exterior wall. Indoor thermal characteristics without and with PCM were analyzed to demonstrate the optimal PCM application method.

As shown in Figure 1, the PCM for the application of building envelope is assumed to be in the form of a mat consisting PCM cells, which is known as plastic encapsulation.

Figure 1. PCM mat with PCM cells.

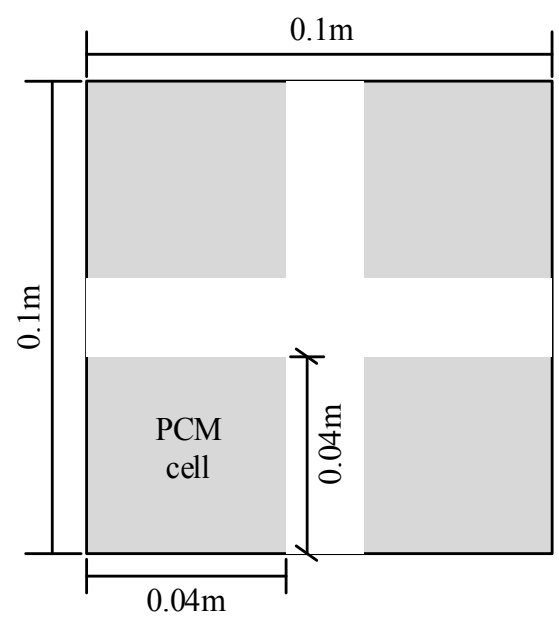

For the input data of the PCM module in EnergyPlus, the PCM cells were assumed to be a continuous layer rather than individual cells. By considering both the mat area and the PCM cells' volume, the thickness of the PCM layer was calculated as follows: 
(1) The PCM contains four PCM cells per $0.1 \mathrm{~m} \times 0.1 \mathrm{~m}(\mathrm{~W} \times \mathrm{L})$ size of mat, with each cell having dimensions $0.04 \mathrm{~m} \times 0.04 \mathrm{~m} \times 0.01 \mathrm{~m}(\mathrm{~W} \times \mathrm{L} \times \mathrm{H})$;

(2) The overall volume of the PCM cells is calculated as: $0.04 \mathrm{~m} \times 0.04 \mathrm{~m} \times 0.01 \mathrm{~m} \times 4$ cell $=$ $0.000064 \mathrm{~m}^{3}$

(3) The mat area is calculated as: $0.1 \mathrm{~m} \times 0.1 \mathrm{~m}=0.01 \mathrm{~m}^{2}$;

(4) Therefore, the PCM cells can be assumed to be a continuous layer with a thickness of $0.0064 \mathrm{~m}$ $\left(=0.000064 \mathrm{~m}^{3} / 0.01 \mathrm{~m}^{2}\right)$.

Dynamic energy simulations have been performed by EnergyPlus 6.0. The basic algorithm used in EnergyPlus for calculating surface heat transfer is the conduction transfer function (CTF). The CTF describes the transient conduction process with time series coefficients in an algebraic equation. While the CTF solution has the advantage of utilizing single and relatively simple linear equations with constant coefficients, the constant coefficients are a disadvantage because it is not possible to simulate temperature-dependent thermal properties. As shown in Figure 2, this problem has been addressed by selecting a new solution algorithm in EnergyPlus, one-dimensional conduction finite difference (CondFD) solution algorithm [7]. The CondFD algorithm in EnergyPlus uses an implicit finite difference scheme, where the user can select Crank-Nicholson or fully implicit.

Figure 2. Control volume for heat conduction in EnergyPlus.

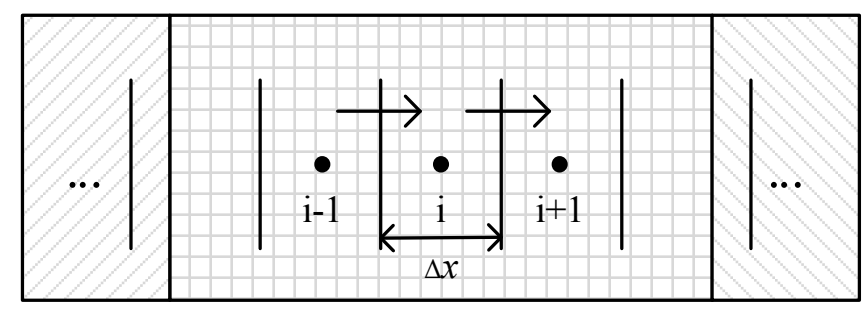

Assuming steady-state conditions, heat conduction from control volume " $i$-1" to control volume " $i$ " can be calculated by Fourier's equation. Through a time-step, the increase in enthalpy for control volume " $i$ " is summed as in Equation (2). Equation (3) is obtained by inserting Equation (1) into Equation (2) and by expressing the specific enthalpy change as a temperature change multiplied by the specific heat capacity. With Equation (4), the specific heat can be updated in each iteration using the Enthalpy-Temperature function, which is based on user-input data. Through these processes node enthalpies get updated at each time step, and the variable properties of the PCM can be analyzed accurately. In the CondFD algorithm, all elements are divided or discretized automatically using Equation (5), which depends on a space discretization constant c, the thermal diffusivity of the material $\alpha$, and the time step. We have used the default space discretization value of three (equivalent to a Fourier number $F_{0}$ of $1 / 3$ ) and input other values:

$$
\begin{gathered}
q_{i}^{j+1}=-\frac{k\left(T_{i}^{j+1}-T_{i-1}^{j+1}\right)}{\Delta x}-\frac{k\left(T_{i+1}^{j+1}-T_{i}^{j+1}\right)}{\Delta x}=-k \frac{T_{i+1}^{j+1}-T_{i-1}^{j+1}}{\Delta x} \\
\frac{\rho \Delta x\left(h_{i}^{j+1}-h_{i}^{j}\right)}{\Delta t}=-\left(q_{i}^{j+1}-q_{i}^{j}\right) \\
\frac{\rho c_{p} \Delta x\left(T_{i}^{j+1}-T_{i}^{j}\right)}{\Delta t}=k \frac{T_{i+1}^{j+1}-T_{i}^{j+1}}{\Delta t}+k \frac{T_{i-1}^{j+1}-T_{i}^{j+1}}{\Delta t}
\end{gathered}
$$




$$
\begin{gathered}
c_{p}=\frac{h_{i}^{j+1}-h_{i}^{j}}{T_{i}^{j+1}-T_{i}^{j}} \\
\Delta \mathrm{x}=\sqrt{\mathrm{c} \cdot \alpha \cdot \Delta t}=\sqrt{\frac{\alpha \cdot \Delta t}{F_{0}}}
\end{gathered}
$$

\subsection{Building Description}

The studied building is an eight-story research building located in Seoul. A floor plan of a typical story is shown in Figure 3. The exterior wall of this building consists of galvanized steel sheet, air cavity, insulation and gypsum board from outside to inside. The area of each floor is $698.7 \mathrm{~m}^{2}$, and this study analyzed the application effects of the PCMs with various phase change temperatures only for the typical floor.

Figure 3. Typical floor plan of the studied building.

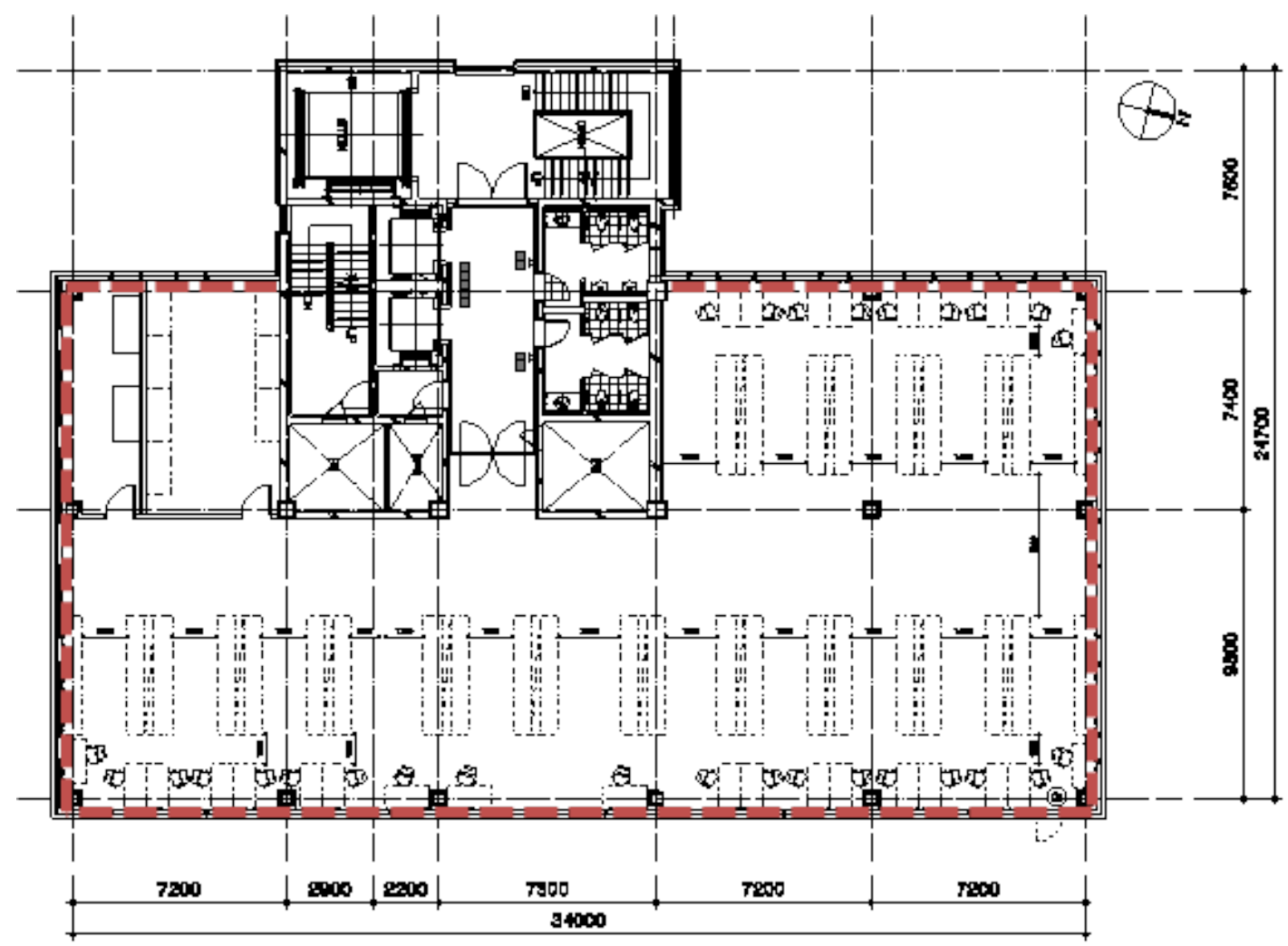

\subsection{Simulation Methods}

The weather data for Seoul in energy plus weather (EPW) file format was used for simulation, which can be obtained from Real-Time Weather Data at Energy Efficiency \& Renewable Energy (EERE). The heat balance algorithm used for the cases of without and with PCM was the finite difference method (FDM), as mentioned above, and the time step was set to be $60 \mathrm{~min}$. General input data, such as the HVAC operation schedule and heating and cooling set-point temperature, were based on the domestic standards in Korea (Building Energy Efficiency Rating System, Building Energy Saving Criteria), and these are described in Table 2. 
Table 2. General input data.

\begin{tabular}{ccc}
\hline \multicolumn{2}{c}{ Category } & Input data \\
\hline \multirow{2}{*}{ Internal heat gain $\left(\mathrm{W} / \mathrm{m}^{2}\right)$} & 6.2 \\
\cline { 2 - 3 } & People & 14 \\
\hline Occupancy $\left(\right.$ person $\left./ \mathrm{m}^{2}\right)$ & 0.11 \\
\hline Lighting density $\left(\mathrm{W} / \mathrm{m}^{2}\right)$ & 20 \\
\hline Ventilation rate $\left(\mathrm{m}^{3} / \mathrm{m}^{2} \mathrm{~h}\right)$ & 6 \\
\hline Equipment $/$ lighting schedule & (Monday-Friday) Begin 09:00, Close 18:00 \\
\hline \multicolumn{2}{c}{$\mathrm{HVAC}$ schedule } & (Monday-Friday) Begin 07:00, Close $18: 00$ \\
\hline \multirow{2}{*}{ Set-point temperature $\left({ }^{\circ} \mathrm{C}\right)$} & Heating & 22 \\
\cline { 2 - 3 } & Cooling & 26 \\
\hline
\end{tabular}

The PCM layer was assumed to be installed between the insulation and the gypsum board of the four-sided exterior wall (Figure 4).

Figure 4. (a) Section without PCM and (b) section with PCM.

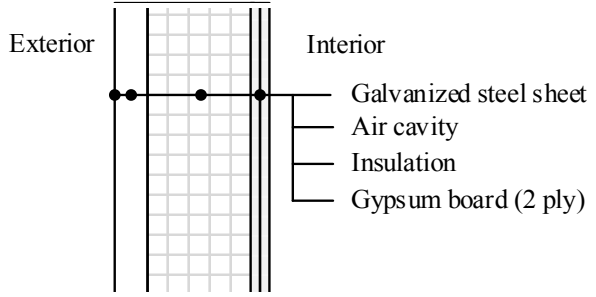

(a)

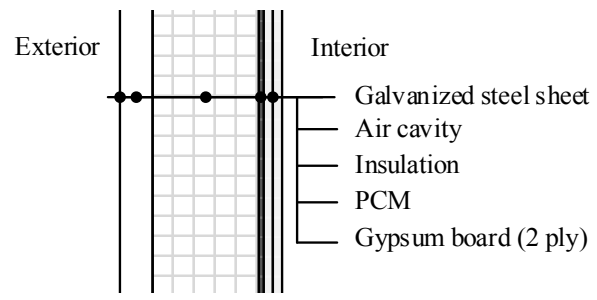

(b)

In addition, the material properties were based on the ASHRAE Handbook Fundamentals 2009 (Table 3). The thermal resistances may be affected by the installation of the PCM. To verify that the addition of the PCM does not cause a significant increase in the thermal resistance, the total thermal resistance values of the wall without the PCM and with the PCM are added to Table 3.

Table 3. Material properties and R-value of the exterior wall.

\begin{tabular}{|c|c|c|c|c|c|c|c|c|c|}
\hline \multicolumn{5}{|c|}{ Without PCM } & \multicolumn{5}{|c|}{ With PCM } \\
\hline Layer & $\begin{array}{c}\text { Conductivity } \\
\text { (W/m K) }\end{array}$ & $\begin{array}{c}\text { Thickness } \\
\text { (m) }\end{array}$ & $\begin{array}{c}\text { Specific heat } \\
(\mathrm{J} / \mathrm{kg} \mathrm{K})\end{array}$ & $\begin{array}{l}\text { Density } \\
\left(\mathrm{kg} / \mathrm{m}^{3}\right)\end{array}$ & Layer & $\begin{array}{c}\text { Conductivity } \\
\text { (W/m K) }\end{array}$ & $\begin{array}{c}\text { Thickness } \\
\text { (m) }\end{array}$ & $\begin{array}{c}\text { Specific heat } \\
\text { (J/kg K) }\end{array}$ & $\begin{array}{l}\text { Density } \\
\left(\mathrm{kg} / \mathrm{m}^{3}\right)\end{array}$ \\
\hline $\begin{array}{l}\text { Galvanized } \\
\text { steel sheet }\end{array}$ & 45.3 & 0.0012 & 5000 & 7830 & $\begin{array}{l}\text { Galvanized } \\
\text { steel sheet }\end{array}$ & 45.3 & 0.0012 & 5,000 & 7830 \\
\hline Air cavity & - & 0.063 & - & - & Air cavity & - & 0.063 & - & - \\
\hline Insulation & 0.02 & 0.1 & 1470 & 30 & Insulation & 0.02 & 0.1 & 1470 & 30 \\
\hline $\begin{array}{c}\text { Gypsum } \\
\text { board }\end{array}$ & 0.18 & 0.0125 & 1000 & 600 & PCM & $0.26 \sim 0.39$ & 0.0064 & $1200 \sim 1550$ & $777 \sim 853$ \\
\hline $\begin{array}{c}\text { Gypsum } \\
\text { board } \\
\end{array}$ & 0.18 & 0.0125 & 1000 & 600 & $\begin{array}{c}\text { Gypsum } \\
\text { board }\end{array}$ & 0.18 & 0.0125 & 1000 & 600 \\
\hline- & - & - & - & - & $\begin{array}{c}\text { Gypsum } \\
\text { board }\end{array}$ & 0.18 & 0.0125 & 1000 & 600 \\
\hline $\begin{array}{l}\text { R-value } \\
\left(\mathrm{m}^{2} \mathrm{~K} / \mathrm{W}\right)\end{array}$ & & & & & & 5.16 & $r$ all types of & M) & \\
\hline
\end{tabular}


The total thermal resistances without the PCM and with the PCM are $5.14 \mathrm{~m}^{2} \mathrm{~K} / \mathrm{W}$ and $5.16 \mathrm{~m}^{2} \mathrm{~K} / \mathrm{W}$, respectively, and the increase with the $\mathrm{PCM}$ is approximately $0.4 \%$. Hence, the thermal resistance of the PCM supporting material can be treated as negligible in the simulation. The "IdealLoadsAirSystem" of EnergyPlus was assumed for the HVAC system. It supplies the necessary heating or cooling air at the specified conditions to meet the zone heating or cooling load without defining air loops, water loops, and so on. The indoor thermal characteristics without the PCM and with the PCM during the heating period and the cooling period were analyzed. In addition, the indoor thermal characteristics during the cooling period with night ventilation were also analyzed.

\section{Simulation Results and Discussions}

\subsection{Heating Operation}

The heating period was set from October to March, and the heating set-point temperature was $22{ }^{\circ} \mathrm{C}$. The simulation results for an annual load, a peak load, and the lowest indoor temperature during the heating period for the cases without the PCM and with the PCM are listed in Table 4. Without the PCM, the annual load is $15,059 \mathrm{~kW} \mathrm{~h}$, the peak load is $134,174 \mathrm{~W}$, and the lowest indoor temperature is $7.89^{\circ} \mathrm{C}$. With the PCM, all annual loads increase slightly, irrespective of the type of PCM. The PCM absorbs sensible heat until the ambient air reaches its melting point, and absorbs a large amount of latent heat at melting point. Therefore, HVAC system should supply more heat to maintain the heating set-point temperature for the case of with PCM.

Table 4. Indoor thermal characteristics of the heating period.

\begin{tabular}{cccc}
\hline PCM & Annual load $(\mathbf{k W}$ h) & Peak load $(\mathbf{W})$ & Lowest indoor temperature $\left({ }^{\circ} \mathbf{C}\right)$ \\
\hline Without the PCM & 15,059 & 134,174 & 7.89 \\
Hexadecane & $15,196(+0.91 \%)$ & $132,318(-1.38 \%)$ & $8.27(+0.38)$ \\
Heptadecane & $15,268(+1.39 \%)$ & $\mathbf{1 2 9 , 8 9 7}(-\mathbf{3 . 1 9 \%})$ & $\mathbf{8 . 7 5}(+\mathbf{0 . 8 6})$ \\
Dodecanol & $15,075(+0.17 \%)$ & $132,925(-0.93 \%)$ & $8.15(+0.26)$ \\
Octadecane & $15,089(+0.20 \%)$ & $133,492(-0.51 \%)$ & $8.03(+0.14)$ \\
\hline
\end{tabular}

In particular, the annual loads with hexadecane and heptadecane increase more than with dodecanol and octadecane because the former PCMs melt at $20{ }^{\circ} \mathrm{C}$ and $21{ }^{\circ} \mathrm{C}$, respectively, which are below heating set-point temperature, $22{ }^{\circ} \mathrm{C}$ (this is demonstrated by the amount of heat flow rate of Figure 5). The most effective material for decreasing the peak load and the lowest indoor temperature appears to be heptadecane, which has a phase change temperature of $21^{\circ} \mathrm{C}$. With heptadecane, the peak load decreases by $3.19 \%$, and the lowest indoor temperature drops by $0.86{ }^{\circ} \mathrm{C}$. 
Figure 5. The lowest indoor temperature curve and the heat flow rate for 13 January.

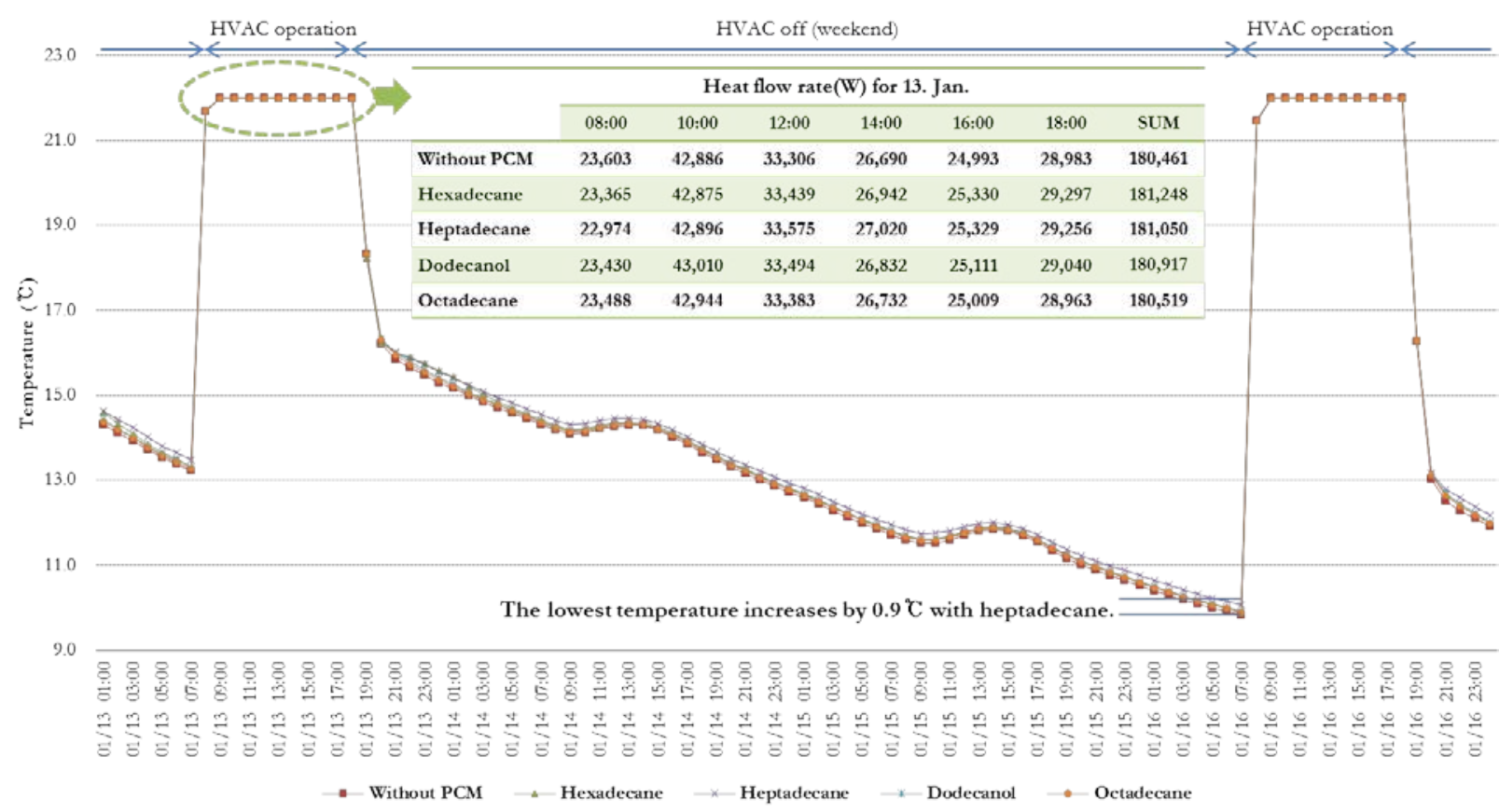

\subsection{Cooling Operation}

The cooling period was set from April to September, and the cooling set-point temperature was $26^{\circ} \mathrm{C}$. The simulation results for an annual load, a peak load, and the highest indoor temperature during the cooling period for the case without the PCM and with the PCM are listed in Table 5. Without the PCM, the annual load is $23,968 \mathrm{~kW} \mathrm{~h}$, the peak load is $68,646 \mathrm{~W}$, and the highest indoor temperature is $35.02{ }^{\circ} \mathrm{C}$. With the PCM, the annual load, the peak load, and the highest indoor temperature all decrease slightly. The most effective material for decreasing the annual load is dodecanol, which has a phase change temperature of $24{ }^{\circ} \mathrm{C}$, and the load decreased by $1.05 \%$. For the peak load and the highest indoor temperature, octadecane, which has a phase change temperature of $29{ }^{\circ} \mathrm{C}$, was the most effective. With octadecane, the peak load decreases by $1.30 \%$, and the highest indoor temperature drops by $0.50{ }^{\circ} \mathrm{C}$.

Table 5. Indoor thermal characteristics of the cooling period.

\begin{tabular}{cccc}
\hline PCM & Annual load $(\mathbf{k W}$ h) & Peak load(W) & Highest indoor temperature $\left({ }^{\circ} \mathbf{C}\right)$ \\
\hline Without PCM & 23,968 & 68,646 & 35.02 \\
Hexadecane & $23,857(-0.46 \%)$ & $68,570(-0.11 \%)$ & $34.90(-0.12)$ \\
Heptadecane & $23,827(-0.59 \%)$ & $68,382(-0.39 \%)$ & $34.70(-0.32)$ \\
Dodecanol & $23,716(-1.05 \%)$ & $68,546(-0.15 \%)$ & $34.87(-0.15)$ \\
Octadecane & $23,736(-0.97 \%)$ & $67,755(-1.30 \%)$ & $34.52(-0.50)$ \\
\hline
\end{tabular}

As a result, the PCM with a phase change temperature near to the cooling set-point temperature $\left(26^{\circ} \mathrm{C}\right)$, is the most efficient for cooling, but the effect was not so considerable. This might be because there was a relatively large difference between the phase change temperature and the cooling set-point temperature. If the PCM with the phase change temperature which is close to the cooling set-point temperature is applied, cooling effects of the PCM will be greater because the PCM can absorb both sensible and latent heat near the cooling set-point temperature. As a result of the thermal characteristic 
analysis during the cooling period under the regular HVAC operation, the use of the PCM does not appear to be very effective. This ineffectiveness might be due to several parameters, such as PCM position, PCM quantity, PCM latent heat capacity, phase change temperature, and HVAC operation schedule. While various studies for each parameter can be performed, this paper analyzed the effect of HVAC operation strategies such as night ventilation. Night ventilation is an energy-saving operational strategy, in which the room is ventilated during the night hours. A night ventilation schedule is set for this study as follows: the outdoor air is induced only when the outdoor air is $2{ }^{\circ} \mathrm{C}$ below the indoor air between 12 a.m. and 7 a.m. during the cooling period. The simulation results for an annual load, a peak load, and the highest indoor temperature during the cooling period with night ventilation for the case without the PCMs and with the PCMs are listed in Table 6. The combination of both night ventilation and the PCM appears to be more efficient for cooling the building. The application of night ventilation decreases the annual load by $7.94 \%$, the peak load by $10.15 \%$, and the highest indoor temperature by $0.19{ }^{\circ} \mathrm{C}$ compared with regular HVAC operation. With both night ventilation and the PCMs, octadecane, which has a phase change temperature of $29{ }^{\circ} \mathrm{C}$, appears to be the most effective for decreasing the peak load and the highest indoor temperature, and dodecanol, which has a phase change temperature of $24^{\circ} \mathrm{C}$, is effective for the annual load. With night ventilation and octadecane, the peak load decreases by $11.33 \%$, and the highest indoor temperature drops by $0.85{ }^{\circ} \mathrm{C}$. With night ventilation and dodecanol, the annual load decreases by $9.28 \%$.

Table 6. Indoor thermal characteristics of the cooling period with night ventilation.

\begin{tabular}{ccccc}
\hline HVAC & PCM & Annual load(kW h) & Peak load(W) & Highest indoor temperature $\left({ }^{\circ} \mathbf{C}\right)$ \\
\hline Regular HVAC & Without PCM & 23,968 & 68,646 & 35.02 \\
\hline & Without PCM & $22,065(-7.94 \%)$ & $61,681(-10.15 \%)$ & $34.83(-0.19)$ \\
\cline { 2 - 5 } Night ventilation & Hexadecane & $21,918(-8.55 \%)$ & $61,662(-10.17 \%)$ & $34.71(-0.31)$ \\
\cline { 2 - 5 } & Heptadecane & $21,861(-8.79 \%)$ & $61,874(-10.30 \%)$ & $34.51(-0.51)$ \\
\cline { 2 - 5 } & Dodecanol & $\mathbf{2 1 , 7 4 3 ( - 9 . 2 8 \% )}$ & $61,656(-10.18 \%)$ & $34.68(-0.34)$ \\
\cline { 2 - 5 } & Octadecane & $21,769(-9.18 \%)$ & $\mathbf{6 0 , 8 6 6 ( - 1 1 . 3 3 \% )}$ & $\mathbf{3 4 . 1 7}(-\mathbf{0 . 8 5})$ \\
\hline
\end{tabular}

It has been demonstrated that the average phase change temperature should be close to the average room temperature to maximize the thermal heat storage [8]. Also the phase change temperature should be narrow to maximize the thermal heat storage in the PCM application. In results from this research, the application of PCM in building envelope is appropriate for the cooling operation rather than the heating operation. It is because the heat flow from the outside to inside can be more absorbed during the cooling operation. In considering the heating and cooling energy saving potential simultaneously, it is preferable to have a wide range of phase change temperature to comply with wide range of the average room temperature variation. Furthermore, the thermal heat can be effectively discharged via night ventilation by increasing the convective heat transfer coefficient [9]. The follow-up study with different parameters such as PCM quantity, PCM position should be followed for investigating an optimal PCM application method [8]. 


\section{Conclusions}

This paper aimed to investigate the energy saving potentials in buildings when various PCMs are applied to the lightweight building envelope by analyzing the thermal loads characteristics according to the various phase change temperatures of the PCMs. For the heating period, the annual load, the peak load, and the lowest indoor temperature were $15,057 \mathrm{~kW} \mathrm{~h}, 134,174 \mathrm{~kW} \mathrm{~h}$, and $7.9{ }^{\circ} \mathrm{C}$, respectively, without the PCM. With the PCM, the annual load for all types of PCM increased because the PCM absorbs heat when the ambient temperature is below its melting point. The peak load decreased by $-3.2 \%$, and the lowest indoor temperature increased by $0.86{ }^{\circ} \mathrm{C}$ with heptadecane (phase change temperature $21^{\circ} \mathrm{C}$ ). In summary, the PCM with a phase change temperature that is the most similar to the heating set-point temperature, $22{ }^{\circ} \mathrm{C}$, is the most efficient for heating. For the cooling period, the annual load, the peak load, and the highest indoor temperature were $23,968 \mathrm{~kW} \mathrm{~h}$, $68,646 \mathrm{~kW} \mathrm{~h}$, and $35.0^{\circ} \mathrm{C}$, respectively, without the PCM. With the PCM, the annual load decreased by $1.05 \%$ with dodecanol (phase change temperature $24^{\circ} \mathrm{C}$ ) and by $0.97 \%$ with octadecane (phase change temperature $29{ }^{\circ} \mathrm{C}$ ). In addition, with octadecane, the peak load decreased by $1.30 \%$, and the highest indoor temperature dropped by $0.5^{\circ} \mathrm{C}$. As a result, the PCM with a phase change temperature that is near to the cooling set-point temperature, $26^{\circ} \mathrm{C}$, is the most efficient for cooling, but the effect was not so considerable. This might be because there was a relatively large difference between the phase change temperature and the cooling set-point temperature. If a PCM with a phase change temperature which is close to the cooling set-point temperature is applied, the cooling effects of the PCM will be greater because the PCM can absorb both sensible and latent heat nears the cooling set-point temperature. In addition, the cases of with both PCM and the night ventilation for cooling period were also analyzed. The combination of the PCM and the night ventilation appeared to be very efficient: the annual load decreased by $9.28 \%$ with dodecanol and by $9.18 \%$ with octadecane, and the peak load and the highest indoor temperature decreased by $11.33 \%$ and $0.85{ }^{\circ} \mathrm{C}$, respectively, with octadecane.

\section{Acknowledgments}

This work was supported by the National Research Foundation of Korea Grant funded by the Korean Government (NRF-2011-0014060).

\section{Conflicts of Interest}

The authors declare no conflict of interest.

\section{References}

1. Baetens, R.; Jelle, B.P.; Gustavsen, A. Phase change materials for building applications-A state of art review. Energy Build. 2010, 42, 1361-1368.

2. Tae, S.; Shin, S. Current work and future trends for sustainable buildings in South Korea. Renew. Sustain. Energy Rev. 2009, 13, 1910-1921.

3. Sharma, A.; Tyagi, V.V.; Chen, C.R.; Buddhi, D. Review on thermal energy storage with phase change materials and applications. Renew. Sustain. Energy Rev. 2009, 13, 318-345. 
4. Tyagi, V.V.; Buddhi, D. PCM thermal storage in buildings: A state of art. Renew. Sustain. Energy Rev. 2007, 11, 1146-1166.

5. Regin, A.F.; Solanki, S.C.; Saini, J.S. Heat transfer characteristics of thermal energy storage system using PCM capsules: A review. Renew. Sustain. Energy Rev. 2008, 12, 2438-2458.

6. Abhat, A. Low temperature latent heat thermal energy storage: Heat storage materials. Solar Energy 1983, 30, 313-332.

7. Tabares-Velasco, P.C.; Christensen, C.; Bianchi, M. Verification and validation of EnergyPlus phase change material model for opaque wall assemblies. Build. Environ. 2012, 54, 186-196.

8. Koo, J.; So, H.; Hong, S.W.; Hong, H. Effects of wallboard design parameters on the thermal storage in buildings. Energy Build. 2011, 43, 1947-1951.

9. Becker, R. Improving thermal and energy performance of buildings in summer with internal phase change materials. J. Build. Phys. 2013, doi:10.1177/1744259113480133.

(C) 2013 by the authors; licensee MDPI, Basel, Switzerland. This article is an open access article distributed under the terms and conditions of the Creative Commons Attribution license (http://creativecommons.org/licenses/by/3.0/). 